\title{
Prevalence of Spousal Abuse among Married Persons in South East Nigeria: Implications for Counselling
}

\author{
Associate Prof. (Mrs) Anna Onoyase ${ }^{1}$, Ph.D. \\ ${ }^{1}$ Department of Guidance and Counselling, Delta State University, Abraka, P.M.B. 1, Abraka, Delta State \\ Nigeria \\ Correspondence: Anna Onoyase, Ph.D., Department of Guidance and Counselling, Delta State University, \\ Abraka, Nigeria
}

Received: November 16, 2018

Accepted: December 7, 2018

Online Published: December 27, 2018

doi:10.5539/ijps.v11n1p7

URL: https://doi.org/10.5539/ijps.v11n1p7

\begin{abstract}
The study investigated prevalence of Spousal Abuse among Married Persons in South-East Nigeria: Implications for Counselling. Three research questions were formulated to guide the study. The research design adopted for the study was Ex-post Facto. The instrument used to collect data for the research was the "Prevalence of Spousal Abuse Among Married Persons Questionnaire" (POSAAMPQ). Content and facial validity of the instrument were established through expert judgement. The instrument has a reliability coefficient of 0.85 using test re-test method. The investigator used 3 research Assistants to administer 230 copies of the questionnaire on 230 respondents married persons in the 3 states where the investigation was conducted. The data collected from the field work were collated and standard deviation and mean score analysis were carried out for the 15 items in order to answer the 3 research questions raised in the study. The benchmark of 2.50 was chosen for either agreeing or disagreeing with each of the 15 items. The study revealed that there was prevalence of economic abuse among the married persons, there was no prevalence of physical abuse among the married persons. Finally, the investigation indicated that there was prevalence of verbal abuse among the married persons. Some of the recommendations include: Spouses should develop mutual respect for themselves and thus refrain from taking their partners' money without permission, couples should have a thorough understanding of their partners so as to avoid issues that may trigger off anger and thereby prevent wanton destruction of properties.
\end{abstract}

Keywords: spousal abuse, married persons

\section{Introduction}

Man is a social being who is always interacting with other human beings and such relationship could be short-lived, lasting, superficial or intimate. Uloho (2016) noted that life is all about relationship, intimacy, companionship and communion. From observed experience, many intimate relationships culminate into marriage. According to Okorodudu (2010), marriage is a sacred and permanent divine contract that is enacted when two adults of the opposite sex decide on their own accord to exchange their formal consent to live a life of love, to care for one another and promote growth and development of their union. Marriages appear to be contracted for various reasons such as companionship, procreation and fulfilment of couples' expectations. The glitz associated with marriages in Nigeria (traditional and church) seems to suggest that marriage life is always blissful. Sadly enough, what transpires after such ceremonies, as Uloho (2016) observed, are disappointments, frustrations and dissatisfactions to the point of divorce. Some of such dissatisfactions may have cropped up due to spousal abuse which could be physical, verbal and economic.

There were several cases of domestic violence in different parts of Nigeria in 2017. Toluwani in Punch Newspaper (2017) reported that between January and September of the year under review, a total of 852 of such cases occurred in Lagos State alone. This depicts the prevalence of domestic violence (including spousal abuse) in Nigeria. Udobang (2018) disclosed that a national demographic and health survey revealed that about a third of all Nigerian women have experienced some forms of physical violence such as battering, marital rape and murder in the hands of their spouses.

The World Health Organisation in (2009) categorized spousal abuse as an intimate partner violence. The United States Centre for Disease Control (2006) classified intimate partner violence into two types: reciprocal and 
non-reciprocal violence. In reciprocal violence, both partners are violent and in non- reciprocal violence, one partner is violent. Other intimate partner violence include: economic, physical verbal, sexual and spiritual abuse.

\subsection{Economic Abuse}

This is a situation in which the abused person is made to depend upon the perpetrator. Oyadeyi (2014) opined that the perpetrators control victims by controlling their access to all of the family resources, time, food, clothing, shelter and money. They (perpetrators) may actively resist the victims from becoming financially self- sufficient as a way of maintaining power and control. Marks (2011) observed that husbands with low educational attainments, low income and low job occupational status are more likely to perpetrate violence against their respective wives. On the other hand, Ovute (2009) has argued that due to high educational status of some women, they tend to command more wages in the job market and hence become more economically buoyant and thus result in low level of economic dependence on their husband. A husband's lack of economic resources and a wife's access to economic independence are destabilizing for a spousal relationship.

\subsection{Physical Abuse}

Abubakar (2014) asserted that physical abuse involves contact intended to cause feelings of intimidation, pain, injury or other physical suffering or bodily harm. Physical abuse also consists of biting, slapping, and pushing of a partner. Agbakwuru and Opara (2011) and Wikipedia (2013) opined that physical violence has the potential of causing injury, harm, disability and death to an individual. For instance Busari (2011) reported that a man in Oyo State South-West Nigeria locked up his wife in a one - room apartment and allegedly beat her to death over paternity scuffle. Instances of physical abuse abound in the media (both electronic and print) and in most cases victims seem to endure such marriages because of the social stigma on dissolution of marriages. Women who divorced their husbands are regarded as prostitutes and do not command any respect in the Nigerian society. In such homes, the emotional climate is usually very tense.

\subsection{Verbal Abuse}

Dabu (2011) regards verbal abuse as an act of hate speech, insults, swearing, curses, coercion and teasing of a person in marriage who is in control of the other verbally. Verbal abuse seems to be the foundation for precipitation of many kinds of violence in Nigerian families. Zamierowski (2010) noted that verbal abuse through heartfelt words shatter couples' relationship. Acts of verbal violence on women include name calling, shaming, insults, quarrelling, criticisms, ridicules, blaming, teasing, questioning and mocking of women that may lead to anger.

\subsection{Sexual Abuse}

The World Health Organisation (2013) stated that sexual abuse consists of sexual harassment, trafficking for the purpose of forced prostitution, forced exposure to pornography, forced pregnancy, forced abortion, forced marriage and female genital mutilation. As far as Abubakar (2014) is concerned, sexual abuse is a situation in which force is used to obtain participation in unwanted sexual activity. Forced sex by a spouse with whom consensual sex has occurred is an act of aggression and violence. It appears that the act of sexual abuse in marriage is perpetrated by male partners on their wives.

Timiun (2012),Onyeakusi (2015) and Dabu (2016) studies revealed that women are not left out in perpetrating violence against men. But, the basic characteristics is the stance between men and women which essentially is based on power relation in Nigerian society where women have less power than men. Women are generally considered not to accomplish any meaningful social, political or educational project without accommodating men. In addition, Section 55(1) of the penal code of Northern Nigeria provides for violence against women by the husband as long as previous hurt is not experienced. This by implication, gives legal backing to some men to perpetrate violence on women particularly in the family.

Anigala and Abidde (2017) investigated perceived causes of domestic violence against women in Warri Metropolis in Delta State, Nigeria. The descriptive survey research method was employed for the study. The simple random sampling technique was used to select 150 respondents from a population of 5000 women that participated in the study. The instrument used to collect data for the study, was "Perception of Causes of Violence Against Women" (POCVAW). The simple percentage and inferential statistics were used to analyse the data collected from the field work. One of the findings showed that lack of self-control by husbands is one of the causes of violence against women.

Usman (2017) carried out a study of secondary school teachers' perceived causes and consequences of intimate partners violence in Niger State, Nigeria. One of the purposes of the study was to investigate the perception of teachers on the causes of intimate partner violence in Niger State, based on gender. The second purpose was to 
find out the consequences of intimate partner violence in Niger State based on religion. The survey technique was adopted for the study. A total of 300 respondents participated in the study. Frequency counts, percentages, mean scores and mean ranking were used to analyse the data collected from the field work. One of the findings indicated that there was no significant difference between the perceptions of teachers as regards causes of intimate partner violence in Niger State, on the basis of gender. The study also revealed that there was no significant difference between the perceptions of teachers as regards consequences of intimate partner violence in Niger State on the basis of religion.

\subsection{Definition of Terms}

Married Persons: These are individuals (males and females) who have married according to the traditional rites of their communities.

Spousal Abuse: In this study, spousal abuse denotes physical, economic and verbal violence on one's partner.

\subsection{Statement of the Problem}

From observation, at wedding ceremonies in Nigeria, couples make vows to love and cherish each other till death finally separates them. Making of these promises is always seen as a serious affair. While some of these married persons appear to have kept their vows, many others do not uphold their promises. In homes where couples make light of their marriage vows, spouses are not respected, their views are not sought, they are beaten up at the slightest provocation, spat at and humiliated. All these are spousal abuse and do not make for mutual understanding among partners. Consequently, the emotional climate in the home becomes so tense and spouses live in fear. Under this situation, couples tend to endure and not enjoy their marriage; excitement and expectations about the union slowly give way to hatred, malice and suspicion amongst others.

The problem of this study put in a question form is: what is the prevalence of spousal abuse among married persons in South - East Nigeria and what are its implications for counselling?

The researcher formulated three research questions to guide the study.

1. What is the prevalence of economic abuse among married persons in South-East Nigeria?

2. What is the prevalence of physical abuse among married persons in South-East Nigeria?

3. What is the prevalence of verbal abuse among married persons in South-East Nigeria?

\section{Research Procedure and Methodology}

The research design adopted for this study was Ex-post Facto. Iweh (2014) stated that Ex-post Facto involves the collection of data on the title of investigation. The design therefore enables the researcher to collect information on the events that had already taken place. The investigator sampled 3 states out of the 5 states that make up South-East Nigeria. The instrument used to collect data for the study was titled "Prevalence of Spousal Abuse Among Married Persons Questionnaire" (POSAAMPQ). The instrument was made up of 15 items, with a 4-point rating scale of "Strongly Agree" (SA) 4- points, "Agree" (A) 3- points, "Disagree" (D) 2 points and "Strongly Disagree" (SD) 1 point. The content and facial validity were established. The reliability of the instrument using the test re-test method was 0.85 .

The investigator used 3 research Assistants to administer 230 copies of the questionnaire on 230 married persons in the 3 states used for the research. However, 224 copies of the questionnaire were retrieved. The data gathered from the field work were collated and standard deviation and mean score analysis were carried out for the 15 items, in order to provide answers to the 3 research questions raised by the researcher in this study. The benchmark of 2.50 was chosen of either agreeing or disagreeing with each of the items on the three tables. 


\section{Findings}

\subsection{Research Question One}

What is the Prevalence of Economic abuse among married persons in South-East Nigeria?

Table 1. Standard Deviation and Mean Score Analysis of prevalence of Economic abuse among married persons in South East Nigeria.

\begin{tabular}{|c|c|c|c|c|c|c|c|c|c|}
\hline $\mathrm{s} / \mathrm{n}$ & Statement & Respondents & SA & A & $\mathrm{D}$ & SD & STD & $\mathrm{X}$ & Decision \\
\hline 1 & $\begin{array}{l}\text { My partner destroys } \\
\text { properties jointly } \\
\text { owned by us when he/ } \\
\text { she is angry }\end{array}$ & 224 & 100 & 80 & 30 & 14 & 0.86 & 3.19 & Agreed \\
\hline 2 & $\begin{array}{l}\text { My spouse has forced } \\
\text { me to keep a joint } \\
\text { account with him }\end{array}$ & 224 & 20 & 26 & 84 & 94 & 0.94 & 1.88 & Disagreed \\
\hline 3 & $\begin{array}{l}\text { My partner withdraws } \\
\text { money from our joint } \\
\text { account without } \\
\text { informing me }\end{array}$ & 224 & 104 & 90 & 20 & 10 & 0.81 & 3.29 & Agreed \\
\hline 4 & $\begin{array}{l}\text { My spouse takes } \\
\text { money from my purse } \\
\text { without permission }\end{array}$ & 224 & 96 & 94 & 24 & 10 & 0.81 & 3.23 & Agreed \\
\hline \multirow[t]{2}{*}{5} & $\begin{array}{l}\text { I do not have access to } \\
\text { our bank account }\end{array}$ & 224 & 21 & 33 & 90 & 80 & 0.92 & 1.98 & Disagreed \\
\hline & Grand Mean & & & & & & 0.87 & 2.71 & Agreed \\
\hline
\end{tabular}

Table one indicated the standard deviation and mean score analysis of the prevalence of economic abuse among married persons in South-East Nigeria. Among the five items on table one, the married persons agreed in items 1, 3 and 4 , that there is prevalence of economic abuse among them. Item 1 has the mean of 3.19, item 3 has a mean of 3.29 and item 4 has a mean of 3.23. Since the 3 items have means above the benchmark of 2.50 , it shows that married persons agreed to the following items: "my partner destroys properties jointly owned by us when he/ she is angry", "my partner withdraws money from our joint account without informing me" and my spouse takes money from my purse without permission.

Item 2 has a mean of 1.88 while item 5 has a mean of 1.98. Since both means are below the benchmark of 2.50, it depicts that the married persons disagreed with the following statements; "my spouse has forced me to keep a joint account with him" and "I do not have access to our bank account". What the researcher can deduce from the above statements is that there is economic abuse among the married persons because the grand mean of 2.71 on table one is above the benchmark of 2.50 . 


\subsection{Research Question Two}

What is the prevalence of physical abuse among married persons in South-East Nigeria?

Table 2. Standard Deviation and Mean Score Analysis of the prevalence of physical abuse among married persons in South-East Nigeria

\begin{tabular}{|c|c|c|c|c|c|c|c|c|c|}
\hline $\mathrm{s} / \mathrm{n}$ & Statement & Respondents & SA & $\mathrm{A}$ & $\mathrm{D}$ & SD & STD & $\mathrm{X}$ & Decision \\
\hline 1 & $\begin{array}{l}\text { Whenever my partner } \\
\text { is angry, he hits me } \\
\text { with any object at his } \\
\text { disposal }\end{array}$ & 224 & 09 & 22 & 93 & 100 & 0.80 & 1.73 & Disagreed \\
\hline 2 & $\begin{array}{l}\text { When my spouse is } \\
\text { upset, he throws things } \\
\text { at me }\end{array}$ & 224 & 10 & 23 & 90 & 101 & 0.82 & 1.74 & Disagreed \\
\hline 3 & My partner beats me & 224 & 100 & 82 & 22 & 20 & 0.94 & 3.17 & Agreed \\
\hline 4 & $\begin{array}{l}\text { My spouse pushes me } \\
\text { violently anytime there } \\
\text { is misunderstanding } \\
\text { between us }\end{array}$ & 224 & 110 & 90 & 11 & 13 & 0.82 & 3.33 & Agreed \\
\hline \multirow[t]{2}{*}{5} & $\begin{array}{l}\text { My partner spits at me } \\
\text { at the slightest } \\
\text { provocation }\end{array}$ & 224 & 14 & 20 & 80 & 110 & 0.87 & 1.72 & Disagreed \\
\hline & Grand Mean & & & & & & 0.85 & 2.33 & Disagreed \\
\hline
\end{tabular}

Table two has shown the analysis of the prevalence of physical abuse among married persons in South-East Nigeria; items 1, 2 and 5 have mean scores of 1.73, 1.74 and 1.72 respectively. Since the mean scores for these items $(1,2$ and 5$)$ are below the benchmark of 2.50 , it revealed that married persons disagreed with the statements below: "whenever my partner is angry, he hits me with any object at his disposal", "when my spouse is upset, he throws things at me" and "my partner spits at me at the slightest provocation". Item 3 and item 4 have mean scores of 3.17 and 3.33 which are above the bench mark of 2.50. Since the grand mean of 2.33is lower than the benchmark of 2.50, it implies that there is no physical abuse among married persons in South-East Nigeria.

\subsection{Research Question Three}

What is the prevalence of verbal abuse among married persons in South East Nigeria?

Table 3. Standard Deviation and Mean score analysis of prevalence of verbal abuse among married persons in South East Nigeria.

\begin{tabular}{llllllllll}
\hline $\mathrm{s} / \mathrm{n}$ & Statement & Respondents & SA & A & D & SD & STD & X & Decision \\
\hline 1 & $\begin{array}{l}\text { My spouse criticises } \\
\text { everything I do }\end{array}$ & 112 & 72 & 30 & 10 & 0.86 & 3.28 & Agreed \\
2 & $\begin{array}{l}\text { My partner ridicules } \\
\text { me in public }\end{array}$ & 92 & 82 & 20 & 30 & 1.02 & 3.05 & Agreed \\
3 & $\begin{array}{l}\text { My spouse snobs me } 224 \\
\text { whenev I ask for } \\
\text { favour }\end{array}$ & 72 & 81 & 20 & 51 & 1.73 & 2.78 & Agreed \\
& $\begin{array}{l}\text { My partner yells 224 } \\
\text { always and instils fear } \\
\text { in me }\end{array}$ & 91 & 72 & 41 & 20 & 0.97 & 3.04 & Agreed \\
$\begin{array}{l}\text { My spouse withholds 224 } \\
\text { important information } \\
\text { from me }\end{array}$ & 10 & 12 & 100 & 102 & 0.79 & 1.89 & Disagreed \\
Grand Mean & & & & & & & & \\
\hline
\end{tabular}


The research has revealed on table 3 that items 1,2, 3 and 4 have means of 3.28, 3.05, 2.78 and 3.04 respectively. These are above the benchmark of 2.50. The respondents consented to the items below: "my spouse criticises everything I do" (item 1), "my partner ridicules me in public" (item 2), "my spouse snobs me whenever I ask for a favour" (item 3) and "my partner yells always and instils fear in me" (item 4). However, item 5, has a mean of 1.89 , which is below the benchmark of 2.50 . What the investigator can deduce from the analysis is that there is verbal abuse among married persons in South- East Nigeria because the grand mean of 2.81 is above the benchmark.

\section{Discussion}

One of the findings of this investigation revealed that, there is prevalence of economic abuse among married persons of South East Nigeria. This finding lends credence to the assertion of Oyadeyi (2014) when he said that perpetrators of economic abuse control their victims by controlling their access to all of the family resources, time food, clothing, shelter and money. The finding of the present investigation gives support to Marks (2011) who observed that husbands with low educational attainment, low income and low job occupational status are more likely to perpetrate economic independence. Though, the investigation revealed that there is economic abuse among the married couples, the situation is not totally so because items 2 and 5 on table one with mean of 1.88 and 1.98 respectively depict that economic abuse does not exist among the married couples of South East Nigeria.

Another finding of the present research indicated, there is no prevalence of physical abuse among married persons in South - East Nigeria. The finding disagrees with Busari (2011) who reported that a man in Oyo State, South-West Nigeria locked up his wife in a one-room apartment and allegedly beat her to death over paternity scuffle. The finding of the present study is at variance with the studies of Anigala and Abidde (2017) which revealed that lack of self control by husbands is one of the causes of violence against women. The finding of the present study contradicts the researches of Timiun (2012), Onyeakusi (2015) and Dabu (2016) which revealed that there is prevalence of physical abuse among married persons of South East Nigeria. This is because their studies showed that women are not left out in perpetrating violence against men. Items 3 and 4 on table two with mean of 3.17 and 3.33 respectively lend credence to the prevalence of physical abuse among married couples of South East Nigeria.

Another finding of this research is that verbal abuse exists among married persons of South-East Nigeria. This finding is in consonance with Zamierowski (2010) who opined that verbal abuse through heartfelt words exist and could shatter couples' relationship. He went on to say that acts of verbal violence on women include shaming, insults, quarrelling, ridicules, teasing, and mocking of women that may lead to anger. To a little extent, verbal abuse does not exist among married couples of South East Nigeria. This is because item 5 on table 3 with mean of 1.89 depict that verbal abuse is not prevalent among married persons of South-East Nigeria.

\section{Conclusion}

The conclusion that may be drawn as a result of the findings, is that there is prevalence of economic and verbal abuses among married couples of South East Nigeria. On the other hand, there is no prevalence of physical abuse among the married persons of South East Nigeria.

\section{Recommendations}

The following recommendations are proposed as a result of the findings and conclusion reached.

1. Spouses should develop mutual respect for themselves and thus refrain from taking their partners' money without permission.

2. Couples should have a thorough understanding of their partners so as to avoid issues that may trigger off anger and thereby prevent wanton destruction of properties jointly owned.

3. Couples should learn to imbibe virtues such as tolerance and self control and resolve marital issues amicably instead of unnecessarily criticising their partners.

4. Married persons (especially male spouse) should desist from the practice of ridiculing or snobbing their wives but regard them as people who deserve some form of respect.

5. State government should establish counselling centres in various communities in the state.

6. Professional counsellors (especially marriage counsellors) should be employed to man such centres so as to handle marital issues that could lead to spousal abuse. 


\section{Counselling Implications}

The following are the counselling implications of the study:

1. Marriage counsellors are needed in every community to teach married persons skills of effective communication in marriage so as to enhance marital adjustment and minimise spousal abuse.

2. Marriage counsellors are to counsel couples on the need to open up when there are unresolved issues that could culminate into hate or anger and might precipitate various forms of spousal abuse, for instance, economic and verbal abuse.

3. Married persons are to be counselled on the physical and psychological effects of economic and verbal abuse on their partners and their consequences on the stability of their marriage.

\section{References}

Abubakar, N. U. (2014). Marital Violence as an Impediment to Stabilize Family Life in Nigeria, Implications for Counselling. Perspectives in Guidance and Counselling Edited by Adegoke, A. A. and Aluede, O.

Agbakwuru, C. \& Opara, I. M. (2011). Incidence of Domestic Violence Against Women in River State. Journal of International Gender Studies (JIGS), (6), 180 - 188.

Anigala, A \& Abidde, E.A. (2017). Perceived causes of domestic violence against women in Warri metropolis, Delta State, Nigeria, Implication for Counselling. The Counsellor, 36(1). Edited by Ali Mburza.

Bruce, S. (2002). A man Campaign Marketing Social Norms to Men to Prevent Sexual Assaults. The report on social norms working paper. $5^{\text {th }}$ July.

Busari, T. (2011). Man allegedly Kills Wife over Child Paternity Scuffle. National Life, Dec. 3, p. 50.

Dabu, J. T. (2016). Effects of rational emotive behaviour therapy on perpetrators of spousal abuse in Makurdi Metropolis in Benue State, Unpublished Ph.D Thesis. Benue State University, Makurdi.

Iweh, G. (2014). Availability, utilization and maintenance of physical facilities in Delta State, Nigeria. Unpublished M.Ed Dissertation, Delta State University Abraka, Nigeria.

Kofi, A. (2006). Report on the United Nations Development Fund for Women UNDFFM Website.

Kyermum, N. (2005). Domestic Violence. The Social Implications Art scope. A Journal of the Arts and Social Sciences, 2(4), 64-75.

Marks, O. (2011). Education and training and the avoidance of financial disadvantage. http://researchacen.edudu.

Nnamdi, I. (2012). An insight against Women Right Violation in Nigeria. A Critique. Journal of Politics and Law, 5(2).

Okorodudu, R.I. (2010). Fundamentals of marriage and family counselling ( $1^{\text {st }}$ Ed.) Abraka: Delta State University Press.

Onyeakusi, N. (2015). International Women's day and Maternal Mortality Peoples. Daily, March, 10, p. 4.

Ovute, A. O. (2009). The Influence of Socio-Economic Status on Basic Science Attainment of Junior Secondary School Students. The Science Teacher Today, 3(1), 6- 14.

Oyadeyi, J. B. (2014). Impact of Domestic Violence on Family Well - Being. Perspectives in Guidance and Counselling: Benin City: Justice - Jeco Printing and Publishing Global.

Timiun, G. A. (2012). Theorizing Cost of Marriage and Mutual Combat Partner Violence: Meta Ethnographic Synthesis of Findings on Types of Marriage Praxis, associated Cost and Partners' Value amongst the TIV people of North Central Nigeria. International Journal of Humanities and Social Sciences, 2(4), 63 - 68.

Toluwani, E. (2017). Year of deadly domestic violence cases. Punch Newspapers, Sunday December 31.

Udobang, W. (2018). We are brought up to think suffering this violence is O.K: domestic abuse in Nigeria. The Guardian, Friday, January.

Uloho, S.O. (2016). Spiritual Wellbeing, Sexual Satisfaction and Marital Adjustment of Married Persons in Delta and Edo States. Unpublished Ph.D Thesis, Delta State University, Abraka, Nigeria.

United States Centre for Disease Control. (2006). Domestic Violence retrieved from www.wikipedia.org/wiki/domesticviolence.

Usman, I. G. (2017). Secondary School Teachers' Perceived Causes and Consequences of Intimate Partner Violence in Niger State, The Counsellor, 36(1), Edited by Ali Mburza. 
Weinsheimer, S. R. I. (2005). Severe intimate partner violence and alcohol use among female trauma patients. Journal of Trauma, 58, 22 -29. https://doi.org/10.1097/01.TA.0000151180.77168.A6

Wikipedia. (2013). Domestic Violence. Retrieved from http://cnmwikipedia.org/wiki/domesticviolence.

World Health Organisation. (2013). Acts of gender based violence against women retrieved from http://www.healthgenderviolence.org

World Health Organization. (2009). Violence prevention: The evidence. World Organisation/Liverpool/John Moores. University Press available at www.whoint/violence.injuryprevention.violence/worldreporter/.

\section{Copyrights}

Copyright for this article is retained by the author(s), with first publication rights granted to the journal.

This is an open-access article distributed under the terms and conditions of the Creative Commons Attribution license (http://creativecommons.org/licenses/by/4.0/). 